\title{
Influence of land use change on the waterbird community of Sihwa Lake, Republic of Korea
}

Eunjae Lee ${ }^{1 \dagger}$, Junghee Sagong ${ }^{2 \dagger}$ and Yohan Lee ${ }^{3^{*}}$ (D)

\begin{abstract}
Background: Land use and development alter mudflat and wetland habitat availability, although mudflats and wetlands provide important stopover habitats for shorebirds during the spring and autumn migrations and support communities of ducks and geese during the winter months in the Republic of Korea. This study investigated land use changes around Sihwa Lake (Republic of Korea) and evaluated the effect of these changes on waterbird community characteristics.

Methods: We conducted a land-use-change analysis at the medium-resolution level using land cover maps for 2001, 2007, 2009, and 2014. Also, a tidal stream survey was conducted in Sihwa Lake and the surrounding reclaimed mudflats every season for 10 years (2003-2012) to identify the seasonal and interannual variations in waterbird species composition. To determine the total annual waterbird species and population counts, species diversity index, and interspecies variations, a TRIM (trends and indices for monitoring data) analysis was used.

Results: Wetland area decreased more than 10\% while agricultural land, barren land, and grassland area increased more than $10 \%$ due to continuous reclamation activities around Sihwa Lake. Barren land later turned into agricultural land or other land use. Sixty-three species and 566,623 individuals were recorded. The number of species, population size, and species diversity index by year and by species showed decreasing trends that were more marked in spring and summer. Furthermore, seasonal and annual variations in waterbird species composition showed decreasing trends in dabbling ducks, herons, grebes, and shorebirds but diving ducks displayed increasing trends. In particular, shorebirds were reduced to a greater extent than other waterbird species because of the reduction and simplification of the intertidal zone, and shallow waters caused by reclamation and road construction.
\end{abstract}

Conclusions: Increased development and construction around Sihwa Lake has altered migratory shorebird populations with a general decline in species diversity and population size. The greatest decline was observed in wading birds, while diving duck populations showed increasing trends.

Keywords: Land use development, Migratory bird populations, Population trends, Waterbird population size

${ }^{*}$ Correspondence: johnlee@yu.ac.kr

${ }^{\dagger}$ Eunjae Lee and Junghee Sagong contributed equally to this manuscript

${ }^{3}$ Department of Forest Resources and Landscape Architecture, Yeungnam University, Gyeongsan, Republic of Korea

Full list of author information is available at the end of the article

\section{Background}

Mudflats along the west coast of the Republic of Korea (ROK) are used by a wide variety of wildlife because the large tidal ranges in this region create an extensive area of intertidal habitat. In particular, mudflats are an important habitat for shorebirds that stopover in the ROK during spring and autumn migrations, as well as ducks and geese that spend the winter months in the ROK (Lee 
et al. 2000). However, over $716 \mathrm{~km}^{2}$ accounting for over $25 \%$ of the entire mudflat area has been reclaimed in the past 20 years for urban and agricultural land expansion in coastal regions, driven by rapid ongoing economic growth that since the 1970s (Ministry of Oceans and Fisheries 2017). Land cover changes can affect the seasonal and interannual assemblage of the waterbird species arriving at major mudflats on the west coast of the Korean Peninsula. While reclaimed lakes with simple environments and long stretches of agricultural land created by reclamation provide adequate habitats for wintering ducks, shorebirds have lost large intertidal areas (Lee 2012).

Sihwa Lake is a manmade reservoir that was built by constructing a dike across Sihwa Bay. It is surrounded by the cities of Ansan, Siheung, and Hwaseong in Gyeonggido. The area around Sihwa Bay was rapidly developed after 1984 because it was a prioritized area for implementing agricultural and industrial land reclamation projects launched by the Ministry of Agriculture, Food, and Rural Affairs and the Ministry of Land, Infrastructure, and Transport in the 1970s.

The key project for this designated area was the construction of the $12.7 \mathrm{~km}$ dike between Bang'a-meori on Daebudo Island in Ansan and Oido Island in Siheung to satisfy the demand for land and secure freshwater resources for agricultural lands and irrigation (Lee 2012). After construction of the Sihwa reclamation dam in 1994, the contamination of Sihwa Lake reached a serious level. Starting in 1997, the Korean government made substantial efforts to address the Sihwa Lake contamination problem by regularly operating sluice gates to allow seawater to flush out contaminated water (Hur et al. 2005). This measure was ineffective, and with continuously increasing pollution levels in Sihwa Lake, the government officially abandoned a plan to desalinate Sihwa Lake in February 2001. A tidal power plant was constructed on the dike in 2004 to expand the seawater circulation system and improve Sihwa Lake water quality (Lee et al. 2004; Lee 2012).

Seawater circulation through hydrology restoration is a major energy source that affects intertidal zone and ecosystem structures. Additionally, the expansion of intertidal areas is an essential prerequisite for the restoration of intertidal zones (Eertman et al. 2002; Neckles et al. 2002). With the recently increased awareness of the importance of intertidal restoration, some developed countries have implemented reverse reclamation programs or created artificial wetlands and intertidal zones (Wataru et al. 2014; Young and Ishiga 2014). The on-going development in Sihwa Lake and the surrounding areas has led to the quantitative and qualitative degradation of wildlife habitats and ecosystem services in intertidal zones. Operating tidal power plants in the Sihwa Lake area has been suggested as an alternative way to improve water quality and restore intertidal zones (Kim and Gu 2015). After the Korean government halted the Sihwa Lake development plan, the intertidal zone in Sihwa Lake has been slowly restored, with a corresponding increase in biodiversity (Ministry of Oceans and Fisheries 2008). Reclaimed land formed to the southern and northern areas of the lake became predominantly grassland ecosystems that provide habitat for wildlife, including birds (Park 2016). In addition to improved water quality, Sihwa Lake has widely varying depths from the deep center to the shallow periphery, offering suitable habitats to a wide variety of migrating and wintering bird species such as diving ducks, dabbling ducks, shorebirds, and herons. Nevertheless, the Sihwa Lake area has been threatened by multiple development projects since 2002, including the Sihwa Multi-Techno Valley (MTV) project to the north of Sihwa Lake, the Songsan Green City project on the southeastern mudflats, the agricultural land reclamation project to the south of Sihwa Lake, and the road construction project within the southern reclaimed land (Lee 2012; Jin et al. 2016). Sihwa Lake biodiversity is vulnerable to these ongoing development projects.

The purpose of this study was to identify land use changes around Sihwa Lake caused by various development projects and identify waterbird trends at Sihwa Lake, and explore possible links between two. This study is crucial to conserve the biodiversity of important ecosystems including wetlands. In particular, this study provides information specific to Sihwa Lake biodiversity that can be used to create a targeted plan to offset the potential negative impact of land use change around Sihwa Lake.

\section{Methods}

\section{Survey site}

Sihwa Lake is located between latitude $37^{\circ} 11^{\prime}-37^{\circ} 20^{\prime} \mathrm{N}$ and longitude $126^{\circ} 34^{\prime}-126^{\circ} 50^{\prime} \mathrm{E}$ (Fig. 1), and administratively belongs to three adjacent cities: Hwaseong, Siheung, and Ansan (National Geographic Information Institute 2019). Sihwa Lake surface area is $56.5 \mathrm{~km}^{2}$, with a lake area of $159.2 \mathrm{~km}^{2}$ that includes inland waters flowing into the lake and a catchment area of $476.5 \mathrm{~km}^{2}$. We conducted a survey on reclaimed land around Sihwa Lake to investigate the impact of land use changes in Sihwa Lake and its surrounding areas on waterbird community characteristics.

\section{Land use change}

Using land cover maps (scale of 1:25,000, image data of resolution $5 \mathrm{M}$ ) provided by the Ministry of Environment (https://egis.me.go.kr) (2019), we investigated the 


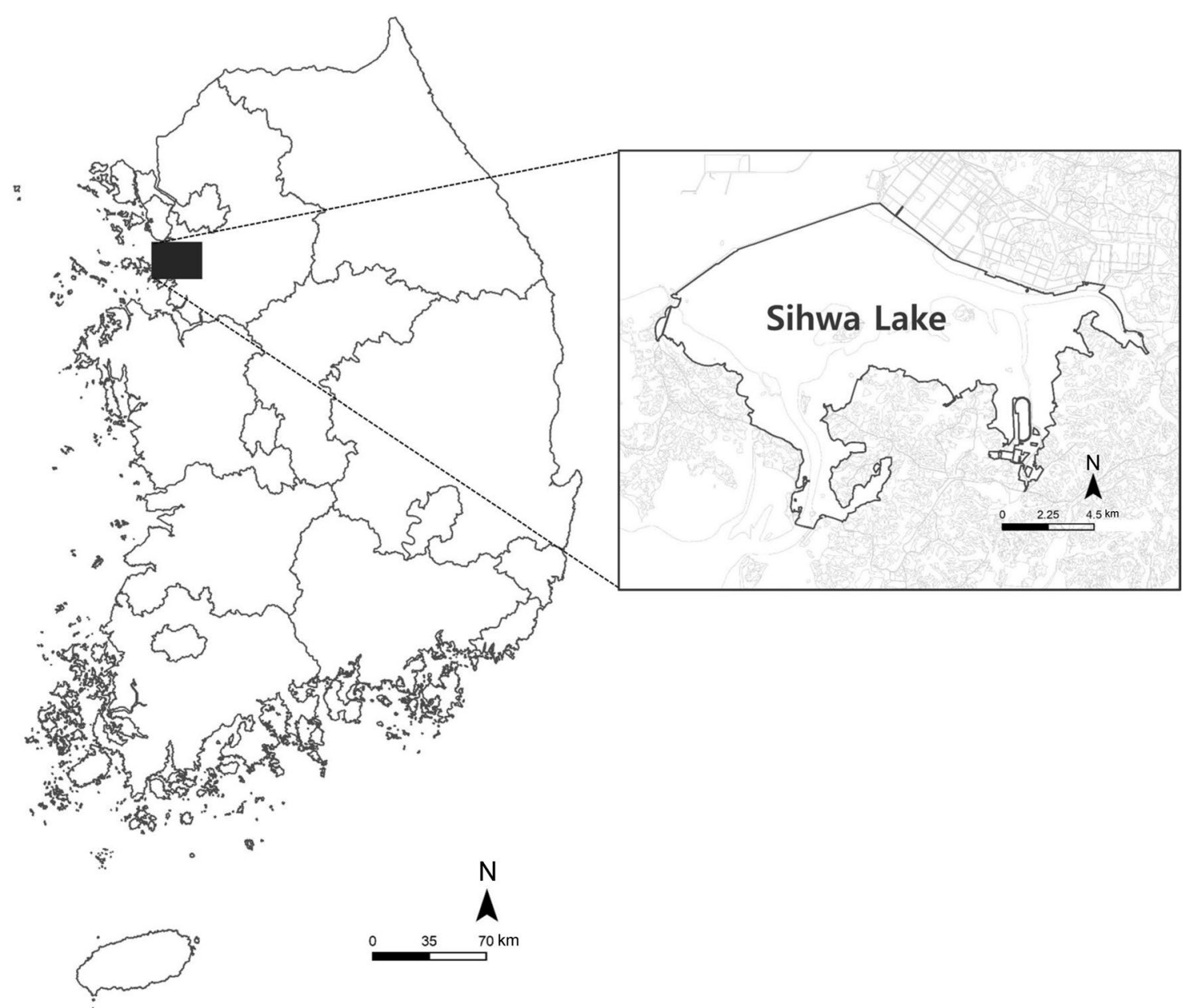

Fig. 1 Location of the Sihwa Lake area in the Republic of Korea

land cover change in and around Sihwa Lake for four selected years: 2001, 2007, 2009, and 2014. The land cover maps were provided in three different resolutions: coarse $(30 \mathrm{~m})$, medium $(5 \mathrm{~m})$, and high $(1 \mathrm{~m})$. Each map was arranged in 7 coarse-resolution, 22 medium-resolution, and 44 fine-resolution categories. For the purposes of this study, coarse- and medium-resolution categories were used to analyze our study site.

The spatial scope of our land cover change analysis was limited to $1 \mathrm{~km}$ from the Sihwa Lake area boundary (Fig. 2). The reference boundary was obtained from the 2001 land cover map (reporting land cover of the year 2000) as that was the first year on-site bird species surveying began. Not only the artificial lake itself (delineated by the roads), but the entire ecologically connected space as of 2000, including inland waters and surrounding wetlands, were defined as Sihwa Lake. The $1 \mathrm{~km}$ distance from the Sihwa Lake boundary was the buffer zone reference distance generally applied to regions of ecological importance as set by the Korean Ministry of Environment.

For the land cover change analysis, distances and the area of each land cover type were calculated using ArcGIS 10.1. The area change ratio of each land cover type was calculated using Excel 2013.

\section{Tidal stream survey}

To identify the seasonal and interannual variations in waterbird species composition, we conducted a tidal stream survey in Sihwa Lake and the surrounding reclaimed mudflats every season (April, July, September, and December) for 10 years (2003-2012). Each survey took place during the day (09:00-18:00). Surveys were performed on clear days, avoiding cloudy, rainy, or snowy days to preclude errors due to weather conditions. Temperature ranges considered suitable for surveying were $15-20{ }^{\circ} \mathrm{C}$ in the spring and autumn, $25-30{ }^{\circ} \mathrm{C}$ in 


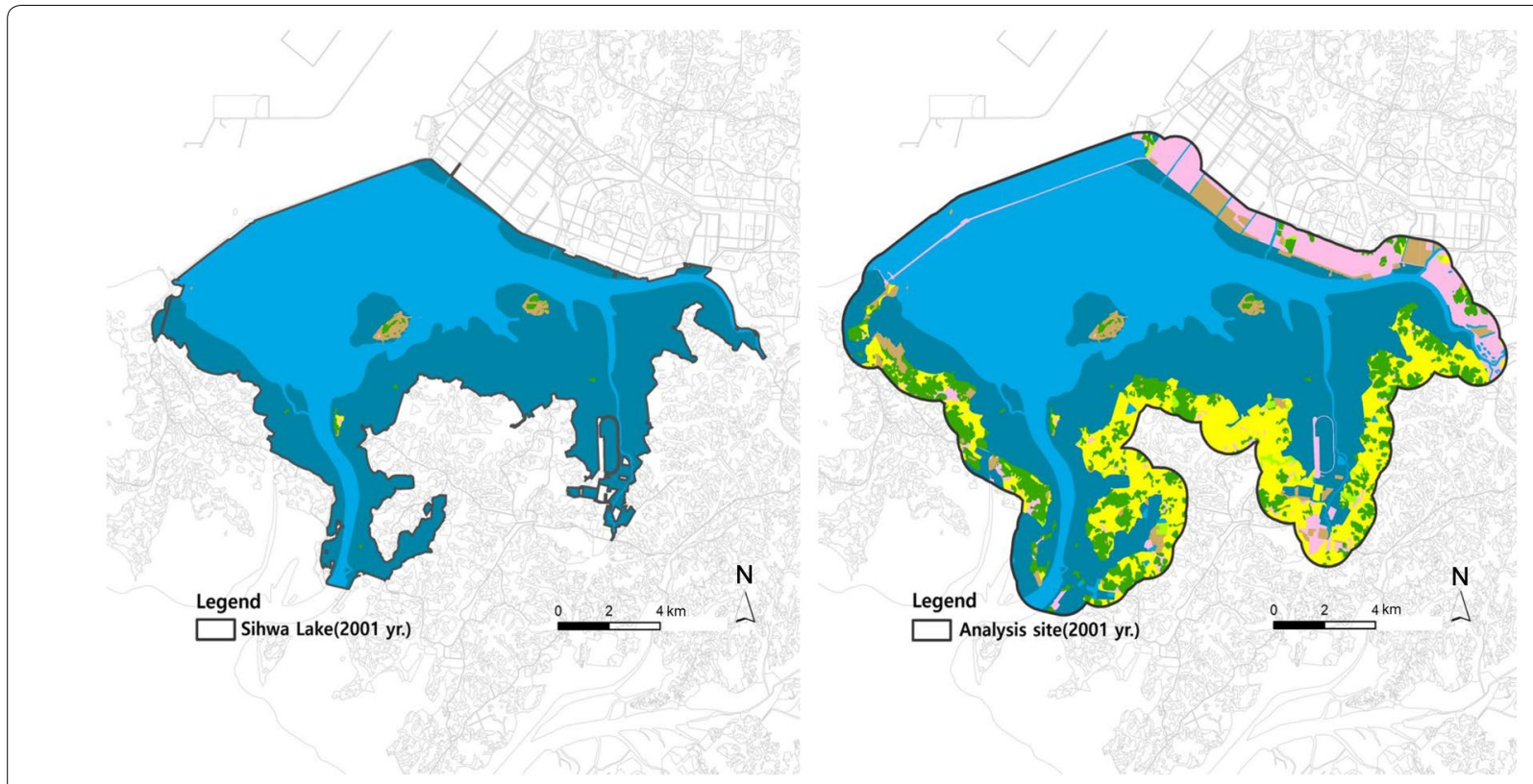

Fig. 2 Sihwa Lake (left) and the analysis site within $1 \mathrm{~km}$ from the boundary (right)

the summer, and $0-5{ }^{\circ} \mathrm{C}$ in the winter before the onset of freezing weather.

To survey bird species, we explored the analysis site by car or on foot, using both line transect and point count methods as well as binoculars (Swarovski $10 \times 42$ ) and telescopes (Swarovski 20-60 $\times$ ) all around the lake. All waterbird species and individual birds observed around Sihwa Lake were recorded as previously described (Bibby et al. 1977). Also we recorded only resting waterbirds to reduce double counting in a single day (Reed et al. 2007).

\section{Data analysis}

Waterbird species and individual birds were counted and the species diversity index $\left(H^{\prime}\right)$ was calculated according to the equation proposed by Shannon and Weaver (1949). To determine the total annual waterbird species and population counts, species diversity index, and interspecies variations, we conducted a TRIM (trends and indices for monitoring data) analysis using the RTRIM package ( $R$ version 3.5.1). TRIM is a program that is useful for bird population trend analyses and widely used for time-series analyses of bird populations (Pannekoek and van Strien 2005; Jin et al. 2016). To evaluate differences in waterbird community composition by season and year, an analysis of similarity was computed using the vegan package in R (ANOSIM; Clarke 1993). We also conducted a simple regression analysis to identify seasonal variations in the number of species, population size, and species diversity index (Jin et al. 2016). To evaluate the annual changes in the number of observed individuals of each species, we used a simple regression. We adopted the results of the analysis if the $R^{2}$ is larger than 0.5 .

\section{Results}

\section{Land use change}

According to the coarse resolution data of the 2001 land cover map, water and wetlands occupied the largest part (68.6\%) of the Sihwa Lake area, followed by agricultural land $(12.9 \%)$, forest $(7.9 \%)$, and used area $(7.6 \%)$. The proportions of grassland and barren land were very low ( 0.4 and $2.5 \%$, respectively). In 2014, the land cover map showed that the water and wetlands area decreased by over $10-57.1 \%$ (from 177.3 to $147.9 \mathrm{~km}^{2}$ ) of the Sihwa Lake area, while agricultural land area increased to $17.3 \%$. Barren land, forest, and used area maintained similar proportions (7.3-7.4\% each) (Fig. 3). The combined area of agricultural land, barren land, and grassland increased by over $10 \%$. Of particular note, compared to 2001, the total land cover area based on the land cover map of Sihwa Lake increased by $29.5 \mathrm{~km}^{2}$ by 2014 and consisted of barren land (42.5\%), agricultural land (38.3\%), and grassland (25.9\%). On the medium resolution data, intertidal area of wetland was sharply decreased by over 30-2.7\% (from 85.4 to $6.9 \mathrm{~km}^{2}$ ), while inland wetland area increased to $23.9 \%$ (from 0 to $62.0 \mathrm{~km}^{2}$ ) of the Sihwa Lake area.

Looking at the spatial distribution of barren land and agricultural land that underwent the largest change in area, barren land increased from $6.5 \mathrm{~km}^{2}$ in the 2001 map to $15.7 \mathrm{~km}^{2}$ in the 2007 map (Fig. 3). In 2014, although the distribution of barren land shifted, the 


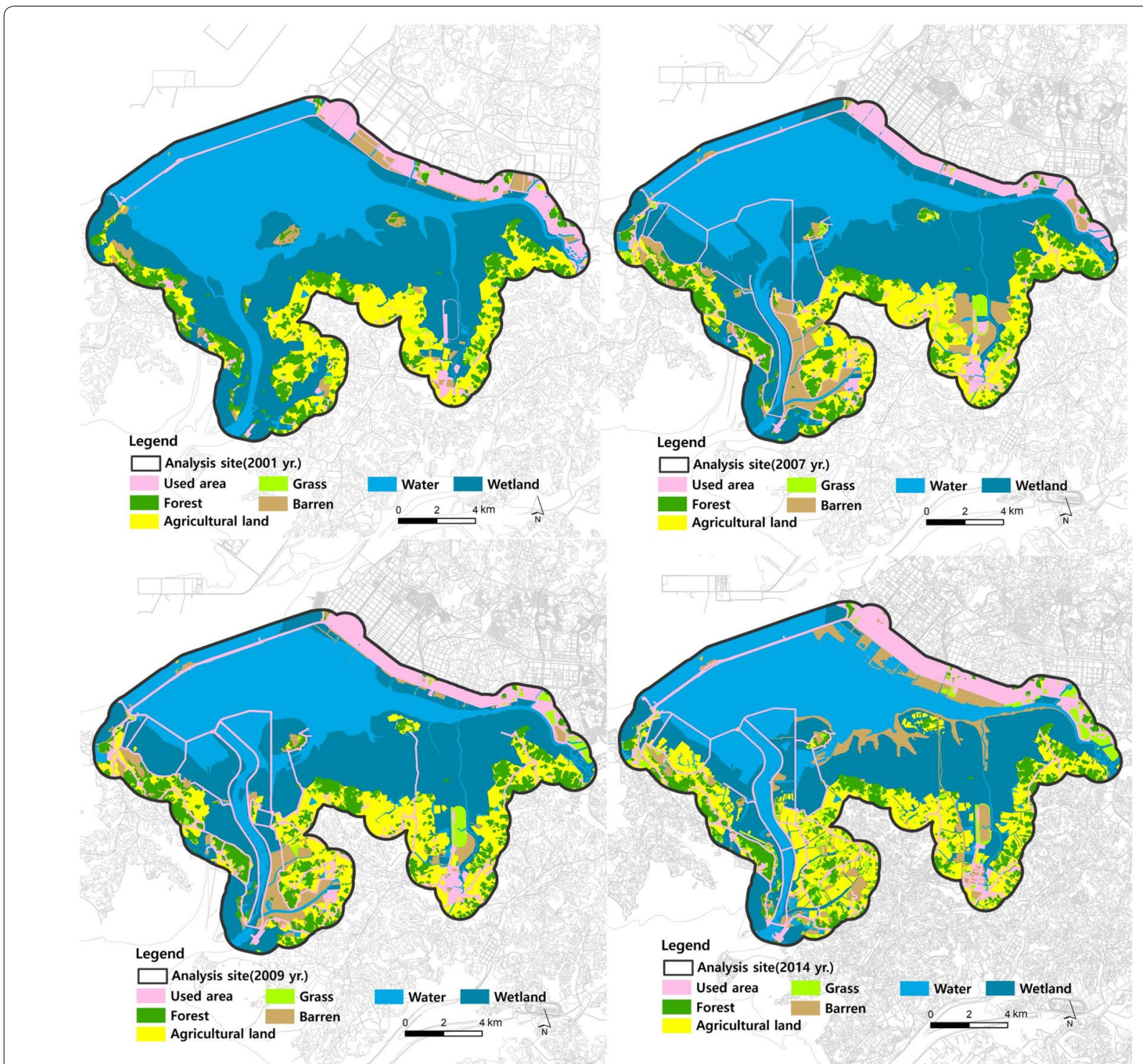

Fig. 3 Time-series land cover changes $(2001,2007,2009,2014)$ in the Sihwa Lake analysis site

overall area was maintained at the 2007 level; barren land adjacent to the mountainous area was changed to agricultural land and wetland adjacent to the used area was changed back to barren land. This was due to ongoing reclamation projects, the implementation of which involved land use changes, such as changing from water and wetlands to barren land and then further to agricultural land or used land (Table 1).

Other than barren land, agricultural land, and grassland, the land use type with the largest increase in area (4.2\%; from 4.6 to $5.8 \mathrm{~km}^{2}$ ) was used land caused by the development of a traffic facility. In particular, the spatial distribution of the traffic facility began to appear in
2007 on space previously occupied by water and wetlands (primary waterbird habitat).

\section{Waterbird community characteristics}

Forty field surveys taken over a 10-year period (20032012) identified a total of 63 waterbird species and 624,623 individuals (Table 2) at the Sihwa Lake. Of 63 species detected in this study, winter visitors were the most dominant (46\%). Also, 16 passage migrants, 13 summer visitors and 5 residents were observed in this study. Most of the waterbirds (57 out of 63) were the least concern and data deficient on the IUCN RedList category, but one endangered (Platalea minor), four 


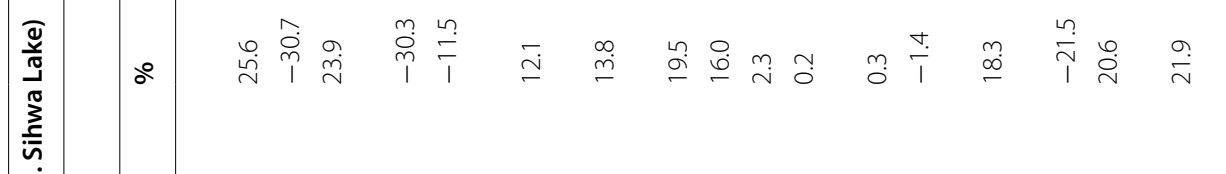

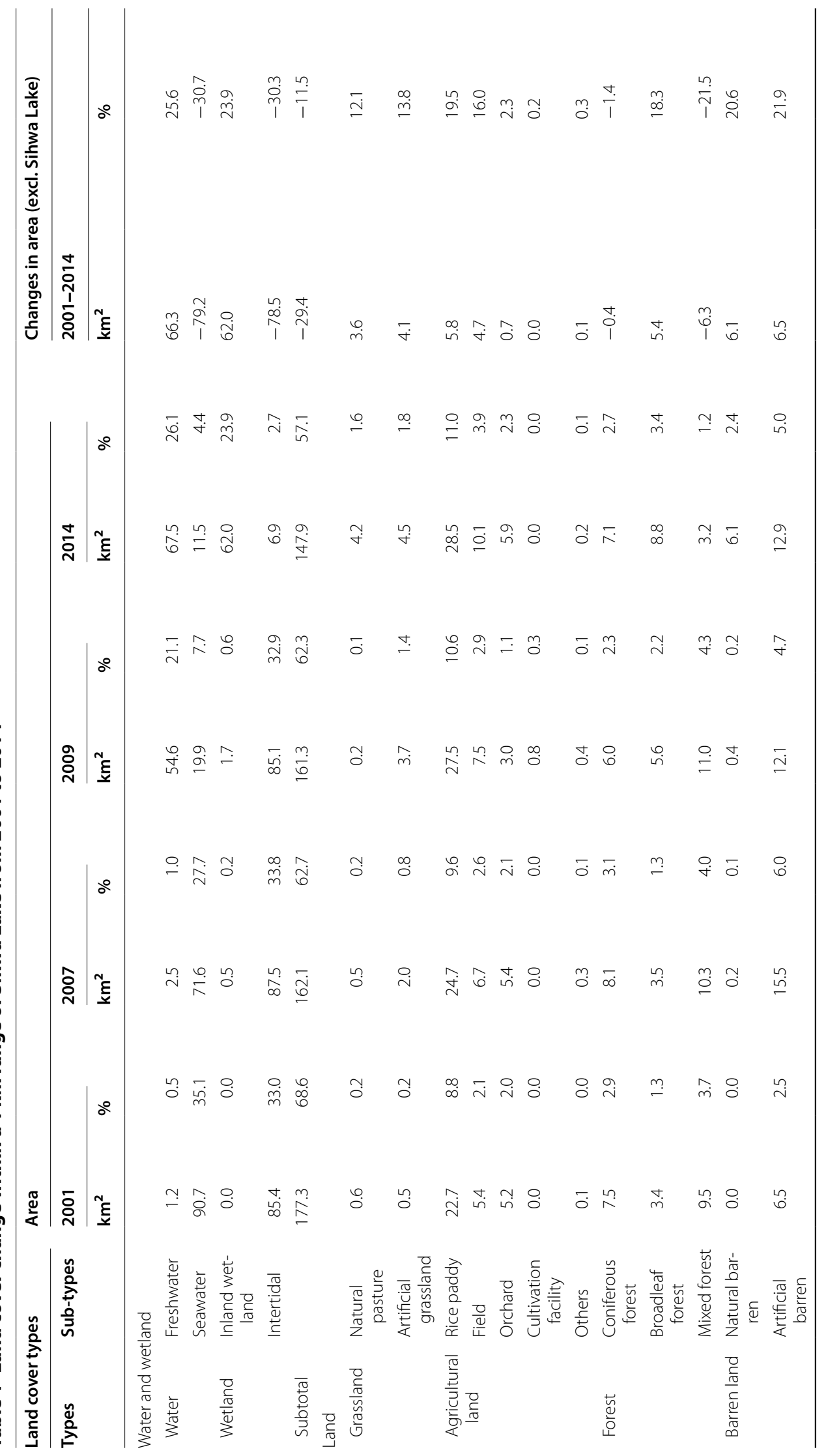




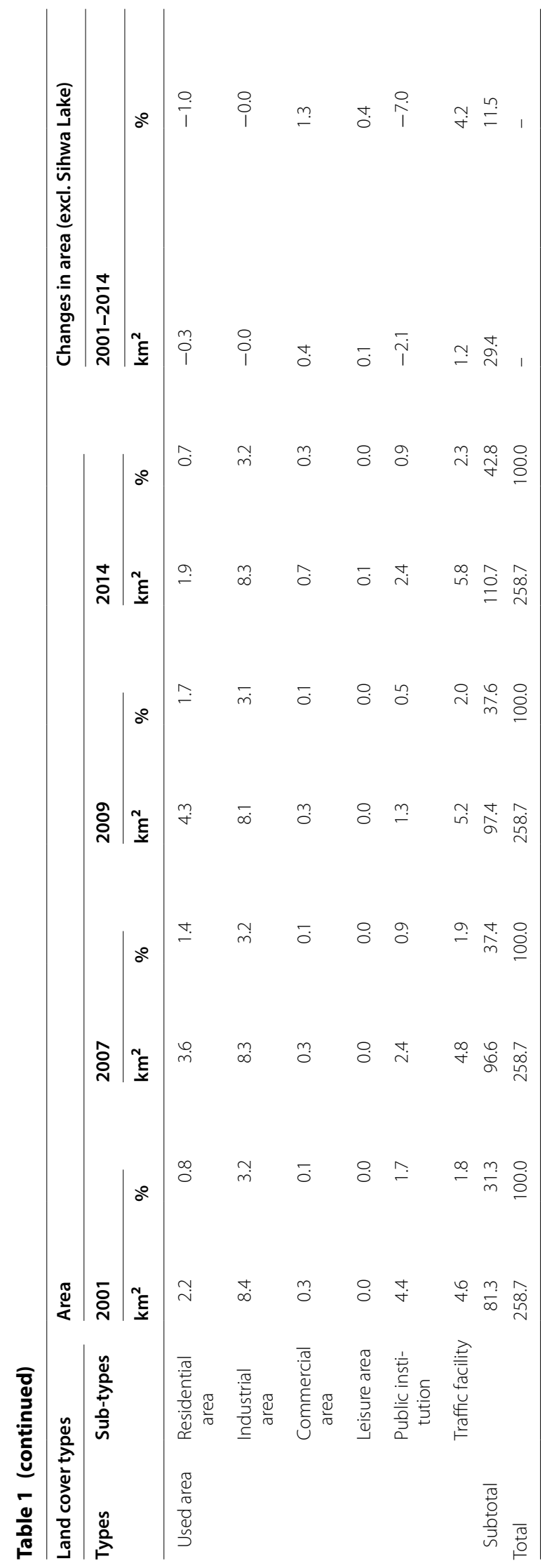


Table 2 The results of waterbird census at the Sihwa Lake between 2003 and 2012

\begin{tabular}{|c|c|c|c|c|c|c|c|}
\hline \multirow[t]{2}{*}{ Species } & \multicolumn{4}{|c|}{ No. of detected individuals (mean \pm SD) } & \multirow{2}{*}{$\begin{array}{l}\text { Migration } \\
\text { pattern }\end{array}$} & \multirow{2}{*}{$\begin{array}{l}\text { IUCN list } \\
\text { catagory }\end{array}$} & \multirow{2}{*}{$\begin{array}{l}\text { Korean } \\
\text { endangered } \\
\text { status }\end{array}$} \\
\hline & Sp. & $\mathrm{Su}$ & $\mathrm{Au}$ & Wi & & & \\
\hline $\begin{array}{l}\text { Tachybaptus } \\
\text { ruficollis }\end{array}$ & $60.2 \pm 42.0$ & $69.4 \pm 42.5$ & $82.2 \pm 44.6$ & $80.9 \pm 47.3$ & R & LC & \\
\hline $\begin{array}{l}\text { Podiceps cris- } \\
\text { tatus }\end{array}$ & $14.0 \pm 9.2$ & $17.0 \pm 9.2$ & $31.0 \pm 9.1$ & $217.0 \pm 9.7$ & $W V / R^{d}$ & LC & \\
\hline $\begin{array}{l}\text { Phalacrocorax } \\
\text { carbo }\end{array}$ & $78.0 \pm 98.8$ & - & - & $965.0 \pm 95.3$ & WV & LC & \\
\hline $\begin{array}{c}\text { Phalacrocorax } \\
\text { capillatus }\end{array}$ & $108.0 \pm 8.4$ & $206.0 \pm 8.3$ & $58.0 \pm 8.3$ & - & $\mathrm{R}$ & DD & \\
\hline Ardea cinerea & $150.0 \pm 37.2$ & $692.0 \pm 37.1$ & $217.0 \pm 37.2$ & $59.0 \pm 37.2$ & SV/R & LC & \\
\hline Egretta alba & $103.0 \pm 105.8$ & $1415.0 \pm 105.1$ & $1828.0 \pm 102.7$ & $76.0 \pm 95.2$ & SV/R & LC & \\
\hline $\begin{array}{l}\text { Egretta inter- } \\
\text { media }\end{array}$ & $9.0 \pm 8.5$ & $119.0 \pm 8.5$ & $117.0 \pm 8.0$ & - & SV & LC & \\
\hline Egretta garzetta & $86.0 \pm 19.6$ & $367.0 \pm 19.6$ & $314.0 \pm 19.5$ & $68.0 \pm 19.3$ & SV/R & LC & \\
\hline $\begin{array}{l}\text { Nycticorax } \\
\text { nycticorax }\end{array}$ & $12.0 \pm 4.1$ & $73.0 \pm 4.0$ & $60.0 \pm 4.0$ & - & SV & LC & \\
\hline $\begin{array}{r}\text { Butorides } \\
\text { striatus }\end{array}$ & $6.0 \pm 2.7$ & $70.0 \pm 2.6$ & $37.0 \pm 2.7$ & - & SV & LC & \\
\hline $\begin{array}{l}\text { Ixobrychus } \\
\text { sinensis }\end{array}$ & - & $15.0 \pm 0.6$ & - & - & SV & DD & \\
\hline Bubulcus ibis & - & $333.0 \pm 27.1$ & - & - & SV & LC & \\
\hline Anser albifrons & - & - & - & $376.0 \pm 26.7$ & WV & LC & \\
\hline Anserfabalis & - & - & - & 8.0 & WV & LC & \\
\hline Cygnus cygnus & - & - & - & 21.0 & WV & LC & $\|$ \\
\hline Grus monacha & - & - & - & 41.0 & WV & VU & $\|$ \\
\hline $\begin{array}{l}\text { Platalea leuc- } \\
\text { orodia }\end{array}$ & - & - & - & $73.0 \pm 48.8$ & WV & LC & $\|$ \\
\hline Platalea minor & - & - & - & $181.0 \pm 100.2$ & SV/R & EN & I \\
\hline $\begin{array}{l}\text { Tadorna fer- } \\
\text { ruginea }\end{array}$ & - & - & - & $420.0 \pm 25.7$ & WV & DD & \\
\hline $\begin{array}{l}\text { Tadorna } \\
\text { tadorna }\end{array}$ & - & - & - & $1302.0 \pm 132.9$ & WV & LC & \\
\hline Anas falcata & - & - & - & $497.0 \pm 184.4$ & WV & LC & \\
\hline Anas penelope & - & - & - & $1830.0 \pm 572.6$ & WV & LC & \\
\hline Anas crecca & - & - & - & $492.0 \pm 181.9$ & WV & LC & \\
\hline $\begin{array}{l}\text { Anas platyrhyn- } \\
\text { chos }\end{array}$ & $8998.0 \pm 5662.6$ & $6228.0 \pm 5665.5$ & $80,198.0 \pm 5654.4$ & $78,650.0 \pm 5625.6$ & WV/R & LC & \\
\hline Anas strepera & - & - & - & 291.0 & WV & LC & \\
\hline $\begin{array}{l}\text { Anas poecilo- } \\
\text { rhyncha }\end{array}$ & $12,350.0 \pm 7159.9$ & $14,640.0 \pm 7177.2$ & $138,100.0 \pm 7170.5$ & $60,490.0 \pm 7148.7$ & WV/R & LC & \\
\hline Anas acuta & - & - & - & $2439.0 \pm 537.1$ & WV & DD & \\
\hline Anas clypeata & - & - & - & $641.0 \pm 178.9$ & WV & LC & \\
\hline Aythya ferina & - & - & - & $176,010.0 \pm 5396.8$ & WV & VU & \\
\hline Aythya fuligula & - & - & - & $1354.0 \pm 177.2$ & WV & LC & \\
\hline Aythya marila & - & - & - & 17.0 & WV & LC & \\
\hline $\begin{array}{c}\text { Bucephala } \\
\text { clangula }\end{array}$ & - & - & - & $95.0 \pm 5.2$ & WV & LC & \\
\hline $\begin{array}{l}\text { Mergus mer- } \\
\text { ganser }\end{array}$ & - & - & - & $903.0 \pm 69.6$ & WV & LC & \\
\hline $\begin{array}{l}\text { Gallinula chlo- } \\
\text { ropus }\end{array}$ & - & $31.0 \pm 2.1$ & - & - & SV/R & LC & \\
\hline Fulica atra & - & $1135.0 \pm 93.4$ & - & - & W/R & LC & \\
\hline
\end{tabular}


Table 2 (continued)

\begin{tabular}{|c|c|c|c|c|c|c|c|}
\hline \multirow[t]{2}{*}{ Species } & \multicolumn{4}{|c|}{ No. of detected individuals (mean $\pm S D$ ) } & \multirow{2}{*}{$\begin{array}{l}\text { Migration } \\
\text { pattern }\end{array}$} & \multirow{2}{*}{$\begin{array}{l}\text { IUCN list } \\
\text { catagory }\end{array}$} & \multirow{2}{*}{$\begin{array}{l}\text { Korean } \\
\text { endangered } \\
\text { status }\end{array}$} \\
\hline & Sp. & Su & $\mathrm{Au}$ & Wi & & & \\
\hline $\begin{array}{l}\text { Himantopus } \\
\text { himantopus }\end{array}$ & - & $1.0 \pm 2.8$ & $5.0 \pm 2.8$ & - & $\mathrm{PM} / \mathrm{SV}$ & LC & \\
\hline $\begin{array}{c}\text { Haematopus } \\
\text { ostralegus }\end{array}$ & - & $6.0 \pm 1.4$ & - & - & $\mathrm{R}$ & DD & $\|$ \\
\hline $\begin{array}{c}\text { Charadrius } \\
\text { placidus }\end{array}$ & - & $31.0 \pm 3.8$ & - & - & $\mathrm{R}$ & LC & \\
\hline $\begin{array}{l}\text { Charadrius } \\
\text { dubius }\end{array}$ & $3.0 \pm 0.9$ & $13.0 \pm 0.9$ & $7.0 \pm 0.9$ & - & SV & LC & \\
\hline $\begin{array}{l}\text { Pluvialis squa- } \\
\text { tarola }\end{array}$ & $80.0 \pm 6.8$ & - & $94.0 \pm 7.1$ & - & PM & LC & \\
\hline $\begin{array}{l}\text { Charadrius } \\
\text { alexandrinus }\end{array}$ & $102.0 \pm 12.3$ & - & $121.0 \pm 11.7$ & - & $\mathrm{PM} / \mathrm{R}$ & LC & $\|$ \\
\hline Limosa limosa & $27.0 \pm 5.2$ & - & $47.0 \pm 5.2$ & - & PM & DD & \\
\hline $\begin{array}{l}\text { Limosalap- } \\
\text { ponica }\end{array}$ & $261.0 \pm 33.5$ & - & $370.0 \pm 34.5$ & - & PM & LC & \\
\hline $\begin{array}{l}\text { Numenius } \\
\text { arquata }\end{array}$ & $1944.0 \pm 169.4$ & - & $1878.0 \pm 162.8$ & - & PM & NT & \\
\hline $\begin{array}{l}\text { Numenius } \\
\text { madagas- } \\
\text { cariensis }\end{array}$ & $352.0 \pm 23.8$ & - & $343.0 \pm 24.8$ & - & PM & LC & $\|$ \\
\hline $\begin{array}{l}\text { Numenius } \\
\text { phaeopus }\end{array}$ & $163.0 \pm 10.1$ & - & $152.0 \pm 10$ & - & PM & LC & \\
\hline Tringa nebularia & $194.0 \pm 18.6$ & $55.0 \pm 18.9$ & $312.0 \pm 18.7$ & - & PM & LC & \\
\hline $\begin{array}{l}\text { Tringa eryth- } \\
\text { ropus }\end{array}$ & 13.0 & - & - & - & PM & LC & \\
\hline $\begin{array}{l}\text { Arenaria inter- } \\
\text { pres }\end{array}$ & 7.0 & - & - & - & PM & LC & \\
\hline $\begin{array}{l}\text { Calidris tenui- } \\
\text { rostris }\end{array}$ & $240.0 \pm 28.9$ & - & $197.0 \pm 28.9$ & - & PM & VU & \\
\hline Tringa glareola & 3.0 & - & - & - & PM & LC & \\
\hline Tringa ochropus & $7.0 \pm 0.5$ & - & - & - & WV & LC & \\
\hline $\begin{array}{l}\text { Actitis hypoleu- } \\
\cos \end{array}$ & $13.0 \pm 0.7$ & - & $13.0 \pm 0.7$ & - & SV & LC & \\
\hline Xenus cinereus & $39.0 \pm 4.4$ & - & $52.0 \pm 4.4$ & - & PM & LC & \\
\hline $\begin{array}{l}\text { Gallinago gal- } \\
\text { linago }\end{array}$ & 1.0 & - & - & - & PM & LC & \\
\hline Calidris alpina & $3015.0 \pm 229.3$ & - & $3604.0 \pm 233.8$ & - & PM & LC & \\
\hline $\begin{array}{l}\text { Larus cras- } \\
\text { sirostris }\end{array}$ & $2577.0 \pm 216.7$ & $2422.0 \pm 213.5$ & $2632.0 \pm 210.2$ & $5560.0 \pm 208.3$ & $\mathrm{R}$ & LC & \\
\hline Larus argentatus & - & - & - & $319.0 \pm 17.8$ & WV & LC & \\
\hline $\begin{array}{l}\text { Larus cachin- } \\
\text { nans }\end{array}$ & - & - & - & $63.0 \pm 4.4$ & WV & DD & \\
\hline $\begin{array}{l}\text { Larus schisti- } \\
\text { sagus }\end{array}$ & - & - & - & $8.0 \pm 4.2$ & WV & LC & \\
\hline Larus saundersi & - & - & - & $1126.0 \pm 34.9$ & WV/R & VU & $\|$ \\
\hline Larus ridibundus & - & - & - & $218.0 \pm 9.5$ & WV & LC & \\
\hline Sterna albifrons & - & 13.0 & - & - & SV/PM & LC & \\
\hline Total & $30,955.0 \pm 15,713.1$ & $27,882.0 \pm 15,752.0$ & $230,787.0 \pm 15,730.1$ & $334,810.0 \pm 15,837.0$ & & & \\
\hline
\end{tabular}

Sp. spring, Su. summer, Au. autumn, Wi. winter, $R$ resident, SV summer visitor, $P M$ passage migrant, $W V$ winter visitor, $D D$ data deficient, $L C$ least concern, $V U$ vulnerable, $N T$ near threatened, $E N$ endangered, $W V / R$ most of the population/some population 
vulnerable (Grus monacha, Aythya ferina, Calidris tenuirostris, Larus saundersi) and one near threatened (Numenius arquata) species were observed at the Sihwa Lake. Also, one endangered level I ( $P$. minor) and seven endangered level II (C. Cygnus, G. monacha, P. leucorodia, Haematopus ostralegus, C. alexandrines, Numenius madagascariensis, L. saundersi) species designated by the Ministry of Environment, Republic of Korea, were recorded in this study.

Seasonal variation in species composition was demonstrated by the changes in dominant waterbird species; the dominant species in spring, summer, and autumn was the Spot-billed Duck (Anas poecilorhyncha), while the Common Pochard (Aythya ferina) was dominant in winter (Table 3). The Spot-billed Duck and the Mallard ( $A$. platyrhynchos) were dominant until 2008. The Common Pochard became the dominant species in 2009. Based on our observations, the number of species, individuals, and species diversity index were high in $2008(24.3 \pm 4.9$, $12,784.5 \pm 26,643.4$, and $2.4 \pm 0.8$, respectively) compared to those in $2012(14.3 \pm 2.5,8723.8 \pm 12,647.9$, and $1.5 \pm 0.8$, respectively).

TRIM analysis used to determine the annual changes in the number of species, number of individuals, and species diversity index showed gradually decreasing trends in the number of species $(-2.2 \%)$, number of individuals $(-1.5 \%)$, and species diversity index $(-0.4 \%)$ (Table 4$)$. In addition, regression analysis of the annual changes in the number of individuals by season revealed decreasing trends in spring $\left(y=-296.05 x+4723.8, R^{2}=0.6756\right)$, summer $\quad\left(y=-218.74 x+3991.3, \quad R^{2}=0.6276\right), \quad$ and autumn $\left(y=-1481.8 x+3122.8, R^{2}=0.1194\right)$ but not in the winter $\left(y=339.46 x+31,633, R^{2}=0.0109\right)$ (Fig. 4$)$.

Our similarity analysis determined the variations in annual and seasonal waterbird species composition and confirmed a significant variation both between years (ANOSIM; $R=0.52, p=0.03$ ) and between seasons (ANOSIM; $R=0.72, p=0.01$ ). By grouping waterbirds into seven categories (dabbling ducks, diving ducks, herons, grebes, shorebirds, gulls, and others), then analyzing the annual change in waterbird species composition in the Sihwa Lake area, decreasing trends were observed in dabbling ducks and herons. In particular, shorebirds demonstrated a steep decline $(-7.8 \%)$. Diving ducks tended to increase (Table 5).

Of 63 waterbird species analyzed in detail, 8 species significantly showed the annual changes. The populations of Arthya ferina $\left(y=1387.6 x-3 \mathrm{E}+06, R^{2}=0.606\right)$, Tachybaptus ruficollis $\left(y=56.224 x-16.533, R^{2}=0.8717\right)$ were annually

Table 3 Waterbird species inhabiting Sihwa Lake during the analysis period (2003-2012)

\begin{tabular}{|c|c|c|c|c|c|c|}
\hline Year & $\begin{array}{l}\text { Mean number } \\
\text { of species }\end{array}$ & Mean $H^{\prime}$ & Total (mean) counts & Min. counts (season) & Max. counts (season) & Dominant species \\
\hline 2003 & $19.8 \pm 2.6$ & $2.3 \pm 0.5$ & $60,843(15,210.8 \pm 15,253.8)$ & 2918 (summer) & 35,491 (winter) & Spot-billed Duck (40.7\%) \\
\hline 2004 & $22.3 \pm 1.7$ & $2.2 \pm 0.5$ & $61,481(15,370.3 \pm 13,391.1)$ & 3492 (summer) & 29,731 (winter) & Mallard (36.6\%) \\
\hline 2005 & $22.0 \pm 1.7$ & $2.1 \pm 0.7$ & $65,293(16,323.3 \pm 16,186.2)$ & 3585 (spring) & 35,114 (autumn) & Mallard (42.4\%) \\
\hline 2006 & $22.3 \pm 2.9$ & $2.0 \pm 0.5$ & $65,868(16,467.0 \pm 14,225.4)$ & 3575 (summer) & 29,536 (autumn) & Spot-billed Duck (39.4\%) \\
\hline 2007 & $23.0 \pm 3.4$ & $2.1 \pm 0.8$ & $64,741(12,063.3 \pm 15,415.0)$ & 3158 (spring) & 34,316 (winter) & Spot-billed Duck (47.9\%) \\
\hline 2008 & $24.3 \pm 4.9$ & $2.4 \pm 0.8$ & $68,990(12,784.5 \pm 26,643.4)$ & 3056 (spring) & 37,962 (winter) & Mallard (35.9\%) \\
\hline 2009 & $19.8 \pm 2.9$ & $1.6 \pm 0.6$ & $48,253(11,280.3 \pm 17,372.8)$ & 2596 (summer) & 39,641 (winter) & Common Pochard (44.0\%) \\
\hline 2010 & $18.0 \pm 2.9$ & $1.7 \pm 1.2$ & $51,138(12,784.5 \pm 18,897.2)$ & 1408 (summer) & 30,409 (winter) & Common Pochard (25.1\%) \\
\hline 2011 & $15.8 \pm 2.9$ & $1.6 \pm 0.9$ & $45,121(11,280.3 \pm 16,266.7)$ & 1705 (spring) & 35,495 (winter) & Common Pochard (57.4\%) \\
\hline 2012 & $14.3 \pm 2.5$ & $1.5 \pm 0.8$ & $34,895$ (8723.8 $\pm 12,647.9)$ & 1624 (spring) & 27,630 (winter) & Common Pochard (58.9\%) \\
\hline Total & $20.1 \pm 3.3$ & $1.9 \pm 0.4$ & $566,623(56,662.3 \pm 45,256.5)$ & - & - & Spot-billed Duck (27.9\%) \\
\hline
\end{tabular}

$H^{\prime}$, species diversity index

Table 4 Species diversity index and number of waterbird species and individuals in the Sihwa Lake area

\begin{tabular}{lcccc}
\hline & Mean counts & SD & Annual change (\%) & $\begin{array}{c}\text { SE } \\
\text { trends (TRIM } \\
\text { classification) }\end{array}$ \\
\hline No. of species & 20.1 & 3.3 & -2.2 & 0.02 \\
No. of individuals & $56,662.3$ & $45,256.5$ & -1.5 & 0.02 \\
$H^{\prime}$ & 1.9 & 0.4 & -0.4 & Moderate decline
\end{tabular}

No., number; SD, standard deviation; $\mathrm{SE}$, standard error; $H^{\prime}$, species diversity index; TRIM, trends and indices for monitoring data 

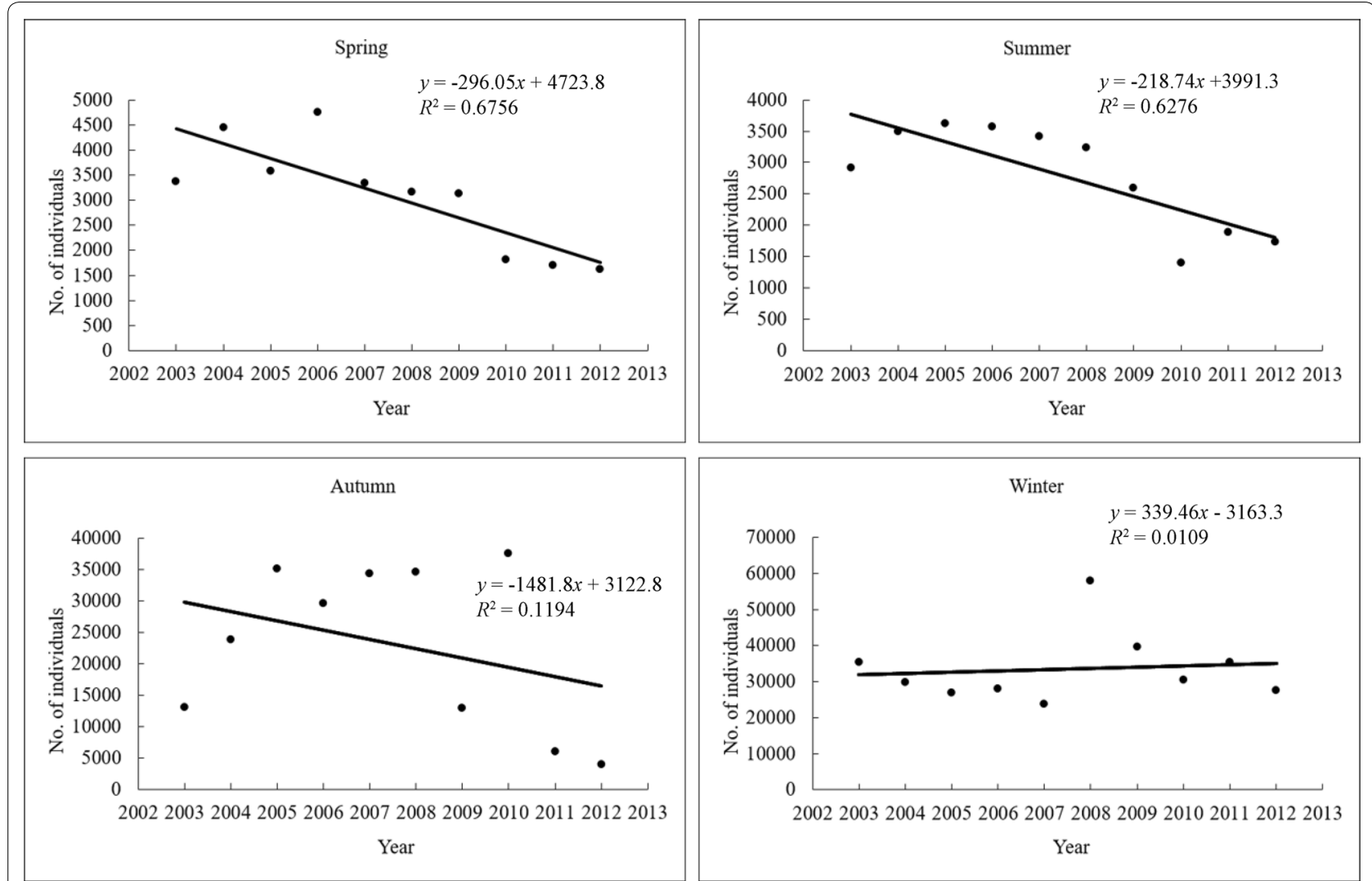

Fig. 4 Annual trends in the number of individual waterbirds by season in the Sihwa Lake area

Table 5 Number of individuals and long-term trends by taxa in the Sihwa Lake area

\begin{tabular}{|c|c|c|c|c|c|}
\hline & Mean counts & SD & Annual change (\%) & SE & $\begin{array}{l}\text { Long-term } \\
\text { trends (TRIM } \\
\text { classification) }\end{array}$ \\
\hline Dabbling ducks & 6658.4 & 4558.5 & -1.2 & 0.01 & Moderate decline \\
\hline Diving ducks & 5945.7 & 3985.2 & 2.7 & 0.01 & Moderate increase \\
\hline Herons & 1058.5 & 685.2 & -0.5 & 0.01 & Moderate decline \\
\hline Grebes & 185.2 & 87.6 & 0.0 & 0.00 & No change \\
\hline Shorebirds & 2525.6 & 1568.3 & -7.8 & 0.03 & Steep decline \\
\hline Gulls & 525.3 & 256.2 & -0.1 & 0.00 & No change \\
\hline Others & 56.2 & 25.6 & 0.1 & 0.01 & No change \\
\hline
\end{tabular}

SD standard deviation, SE standard error, TRIM trends and indices for monitoring data

increased while the populations of Anas platyrhynchos $\left(y=-1456.3 x+22,503, \quad R^{2}=0.6794\right)$, Anas poecilorhyncha $\left(y=-1918.6 x+28,720, R^{2}=0.5304\right)$, Pluvialis squatarola $\left(y=-3.9636 x+39.2, R^{2}=0.6242\right)$, Numenius arquata $\left(y=-101.96 x+943, R^{2}=0.8014\right)$, Actitis hypoleucos $\left(y=-0.6182 x+6, R^{2}=07804\right)$ and Calidris alpina $\left(y=-132.52 x+1390.7, R^{2}=0.6366\right)$ were decreased (Fig. 5).

\section{Discussion}

Mudflats on the western coast of the ROK provide stopover sites for shorebirds during their spring and autumn migrations as well as wintering sites for winter ducks. However, over the last three decades, many mudflats have disappeared due to the construction of Saemangeum, Namyang Bay, and Yeongjongdo New Airport, which critically impacts many waterbirds undergoing their seasonal migration to or through the ROK (Lee et al. 2000). 


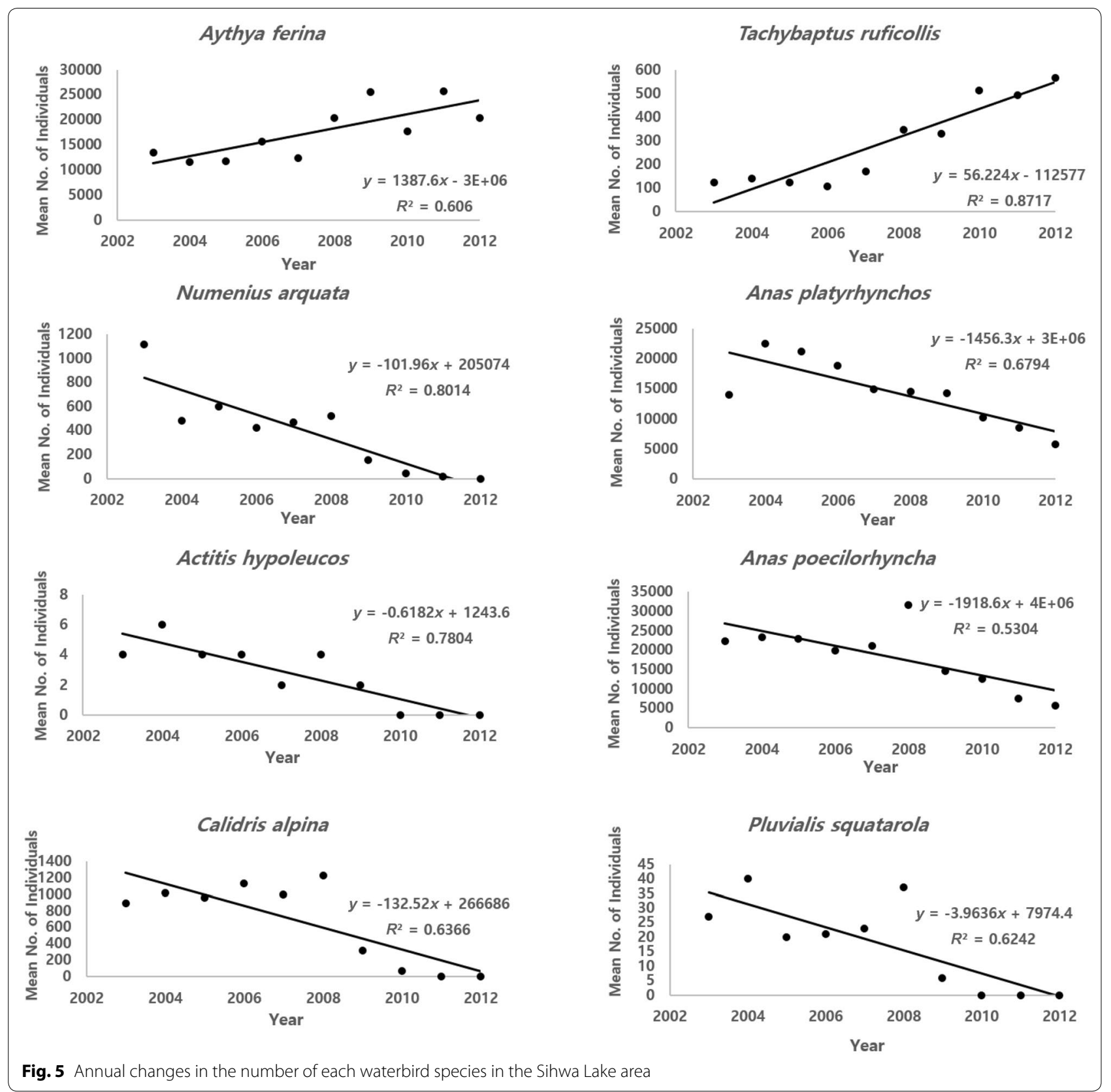

Construction of the Sihwa Dike to create Sihwa Lake has caused water pollution and deteriorated wildlife habitat. However, since the late 1990s, the improved water quality and changes in water levels from the regular circulation of seawater to flush out contaminated water helped to create mudflats with an environment similar to the natural intertidal zone. Nevertheless, road construction and other development projects on the northern, southern, and eastern areas of the Sihwa Lake area continually threaten wildlife habitat by causing the quantitative and qualitative degradation of these habitats (Jin et al. 2016). The analysis of land cover maps from 2001 to 2014 showed trends of diminishing intertidal zones resulting from various development projects, which is consistent with previous findings (Kim and Gu 2015).

The arrival and distribution of waterbirds depend on the availability of food sources and resting areas that are safe from human activities (Lee et al. 2004). Recent changes in the environment of Sihwa Lake area habitats have affected waterbird populations. The number of waterbird species, number of individuals, and species diversity index have gradually decreased because 
development projects have caused quantitative and qualitative degradation in waterbird habitats, especially the intertidal zone (Kim and Gu 2015; Jin et al. 2016). While the number of individual waterbirds tended to decrease in the spring and summer, no significant variations in the number of individual waterbirds were observed in autumn and winter. In addition, the annual variation of waterbirds by species revealed decreasing trends in dabbling ducks, shorebirds, and herons but an increasing trend in diving ducks. These results imply that various development projects such as road construction that decrease shallow waters and form a simple environment with deep water habitat offset the effects of habitat loss in terms diving duck populations in the Sihwa Lake area. Although the individual numbers of dabbling ducks (such as the Spot-billed Duck and Mallard, the dominant species in autumn and winter) in the ROK decreased, the individual numbers of diving ducks (such as the Common Pochard) increased, thus offsetting the potential decrease of the total waterbird population (Baek et al. 2008; Jin et al. 2016). Diving ducks usually forage at a depth ranging from 1 to $4 \mathrm{~m}$, while dabbling ducks, shorebirds, and herons prefer shallower waters (Cramp and Simmons 1978).

Among the seven waterbird categories (dabbling ducks, diving ducks, herons, grebes, shorebirds, gulls, and others), shorebirds populations decreased the most. Shorebirds are typically long-haul migratory birds that breed in the northern hemisphere and migrate to the southern hemisphere for the winter months. As a major wetland stopover site for migratory shorebirds on the East-Asian Australasian Flyway (EAAF; a representative shorebirds migratory route), the mid-west region of the Korean Peninsula is becoming increasingly important (Kim et al. 1994). However, according to the International Union for Conservation of Nature (IUCN), the biodiversity of EAAF intertidal zones has been rapidly declining, and associated ecological services are being lost at an increasing rate. In particular, IUCN pointed out the Yellow Sea side of the Korean Peninsula as the most vulnerable region (Mackinnon et al. 2012). Over $60 \%$ of the salt marshes in the ROK have disappeared over the past 50 years, which has led to a steady decline (5-9\% every year) in waterbird populations (Choi et al. 2014). Therefore, the steep decline trends of the shorebird population at Sihwa Lake could be caused by declines of the shorebird population along EAAF (Amano et al. 2010; Clemens et al. 2016; Piersma et al. 2016; Studds et al. 2017) and the intertidal zone at Sihwa Lake. Future research may need to focus on the changes in water quality and intertidal zones caused by operating a tidal power plant to determine its impact on waterbird populations.

\section{Conclusions}

In conclusion, increased development and construction around Sihwa Lake has altered migratory shorebird populations with a general decline in species diversity and population size. The greatest decline was observed in wading birds, while diving duck populations showed increasing trends. Knowledge of which species are most affected by land use changes around Sihwa Lake will enable the development of specific mitigation policies to stabilize bird populations by ensuring adequate habitat varieties to support the wide range of species that utilize this area.

\section{Acknowledgements}

We appreciate anonymous reviewers who provided valuable comments. Their suggestions helped us to improve our manuscript.

\section{Authors' contributions}

Conception: EL, YL. Data collection: EL, JS. Data analysis: EL, JS. Writing: EL, YL. Revision of the work: EL, JS, YL. All authors read and approved the final manuscript.

\section{Funding}

This was supported by 2020 Yeungnam University Research Grant.

\section{Availability of data and materials}

The datasets used during the current study are available from the corresponding author on reasonable request.

\section{Ethics approval and consent to participate}

Our study was carried out in agreement with the Law of the Republic of Korea on the Protection of Wild life and was approved by the Ministry of Environment.

\section{Consent for publication}

Not applicable.

\section{Competing interests}

The authors declare that they have no competing interests.

\section{Author details}

${ }^{1}$ Urban Planning Research Division, Daejeon Sejong Research Institute, Daejeon, Republic of Korea. ${ }^{2}$ Dept. of Spatial \& Environmental Planning, Chungnam Institute, Gongju, Republic of Korea. ${ }^{3}$ Department of Forest Resources and Landscape Architecture, Yeungnam University, Gyeongsan, Republic of Korea.

Received: 26 March 2020 Accepted: 8 September 2020

Published online: 24 September 2020

\footnotetext{
References

Amano T, Székely T, Koyama K, Amano H, Sutherland WJ. A framework for monitoring the status of populations: an example from wader populations in the East Asian-Australasian flyway. Biol Conserv. 2010;143:2238-47.

Baek IH, Kim HJ, Jin SD, Yu JP, Baek WK. Population status of wintering waterbirds Aythya ferina in Sihwa lake. Korean J Environ Ecol. 2008;1:1-2 (in Korean).

Bibby CJ, Burgess ND, Hill DA. Bird census techniques. London: Academic Press; 1977. p. 257.

Choi SH, Nam HK, Yoo JC. Characteristics of population dynamics and habitat use of shorebirds in rice fields during spring migration. Korean J Environ Agri. 2014;33:334-43 (in Korean).

Clarke KR. Non-parametric multivariate analyses of changes in community structure. Aust J Ecol. 1993;18:117-43.
} 
Clemens RS, Rogers DI, Hansen BD, Gosbell K, Minton CDT, Straw P, et al. Continental-scale decreases in shorebird populations in Australia. Emu. 2016;116:119-35.

Cramp S, Simmons K. Handbook of the birds of Europe the Middle East and North Africa. Oxford: Oxford University Press; 1978. p. 732

Eertman RHM, Komman BA, Stikvoort E, Verbeek H. Restoration of the Sieperda tidal marsh in the scheldt estuary, the Netherlands. Restor Ecol. 2002;10:438-49.

Environmental Geographic Information Service (EGIS), Ministry of Environment, Republic of Korea. 2019. https://egis.me.go.kr. Accessed 13 July 2019.

Hur WH, Lee WS, Rhim SJ. Changes in bird community in artificial wetlands of Sihwa lake. South Korea Korean J Environ Ecol. 2005;19:279-86 (in

\section{Korean).}

Jin SD, Paik IH, Park CY, Choi SH, Yu JP, Paek WK, et al. Some effects of environmental changes on Sihwa reclaimed land on the inhabit of Spot-billed ducks. Korean J Ornithol. 2016;25:87-93 (in Korean).

Kim MK, Gu BJ. The intertidal area in lake Sihwa after operation of the tidal power plant. J Korean Soc Mar Environ Energy. 2015;18:310-6 (in Korean).

Kim HB, Yoo JC, Won PO. Seasonal fluctuations, biometrics, fat and non-fat masses of Dunlines Calidris alpine sakhalina migrating to Sammok island on the west coast of Korea. Korean J Ornithol. 1994;1:15-24.

Lee HK. Changes in relcamation project of Sihwa and environmental policy in Korea. Environ Law Polic. 2012;9:153-73 (in Korean).

Lee HS, Lee JY, Kim WJ, Park SG. Effect of water level fluctuation to the waterbird community in Siwha reservoir. Korean J Environ Ecol. 2000;1:99-102 (in Korean).

Lee SW, Song MJ, Lee HJ, Paek KW. Conservation and status of waterbirds on Sihwa lake. Korean J Environ Ecol. 2004;1:116-20 (in Korean).

MacKinnon J, Verkuil YL, Murray N. IUCN situation analysis on East and Southeast Asian intertidal habitats, with particular reference to the Yellow Sea (including the Bohai Sea). Occasional Paper of the IUCN Species Survival
Commission No. 47. Gland, Switzerland and Cambridge: IUCN; 2012. p. 9-14.

Ministry of Oceans and Fisheries. The project of Sihwa environmental improvement-ecosystem monitoring in Sihwa Lake. 2008. p. 9-662 (in Korean). Ministry of Oceans and Fisheries. The mudflat in Korea. 2017 (in Korean).

National Geographic Information Institute. National land information platform. 2019. https://www.ngii.go.kr/eng/main.do. Accessed 21 July 2019.

Neckles HA, Dionne M, Burdick DM, Roman CT, Buchsbaum R, Hutchins E. A monitoring protocol to assess tidal restoration of salt marshes on local and regional scales. Restor Ecol. 2002;10:556-63.

Pannekoek J, Van Strien AJ. TRIM 3 manual. Trends and indices for monitoring data. CBS. Voorburg: Statistics Netherlands; 2005.

Park CY. Study on the influence of bird community structure and distribution according to restoration of intertidal zone. PhD Thesis. Chung-Nam: Chung Nam Univeristy. 2016. p. 154 (in Korean).

Piersma T, Lok T, Chen Y, Hassell CJ, Yang H-Y, Boyle A, et al. Simultaneous declines in summer survival of three shorebird species signals a flyway at risk. J Appl Ecol. 2016:53:479-90.

Reed JM, Elphick CS, Zuur AF, Leno EN, Smith GM. Time series analysis of Hawaiian waterbirds. Anal Ecol Data. 2007;1:615-31.

Shannon CE, Weaver W. The mathematical theory of communication. Urbana: University of Illinois Press; 1949. p. 64.

Studds CE, Kendall BE, Murray NJ, Wilson HB, Rogers DI, Clemens RS, et al. Rapid population decline in migratory shorebirds relying on Yellow Sea tidal mudflats as stopover sites. Nat Commun. 2017:8:14895.

Wataru N, Yoichi N, Satoshi N, Tetsuji O, Tsuyoshi I, Mitsumasa O. Macrobenthic succession and characteristics of a man-made intertidal sandflat constructed in the diversion channel of the Ohta river estuary. Mar Pollut Bull. 2014;82:101-8.

Young SM, Ishiga $\mathrm{H}$. Environmental change of the fluvial-estuary system in relation to Arase dam removal of the Yatsushiro intertidal, SW Kyushu Japan. Environ Earth Sci. 2014;72:2301-14.
Ready to submit your research? Choose BMC and benefit from:

- fast, convenient online submission

- thorough peer review by experienced researchers in your field

- rapid publication on acceptance

- support for research data, including large and complex data types

- gold Open Access which fosters wider collaboration and increased citations

- maximum visibility for your research: over 100M website views per year

At BMC, research is always in progress.

Learn more biomedcentral.com/submissions 